\title{
Formulation and evaluation of orally disintegrating clopidogrel tablets
}

\author{
Gamal Mohamed Mahrous ${ }^{1, *}$, Mohamed Gabr Kassem², Mohamed Abbas Ibrahim ${ }^{1,3}$, \\ Sayed Hassan Auda ${ }^{1,3}$
}

${ }^{1}$ Department of Pharmaceutics, College of Pharmacy, King Saud University, Riyadh, Kingdom of Saudi Arabia, ${ }^{2}$ Department of Pharmaceutical Chemistry, College of Pharmacy, King Saud University, Riyadh, Kingdom of Saudi Arabia, ${ }^{1}$ Department of Pharmaceutics and Industrial Pharmacy, College of Pharmacy, Al Azhar University, Assiut, Egypt

Recent advances in drug delivery systems have aimed to achieve better patient compliance. One of these advances is the formulation of orally disintegrating tablets (ODTs) that dissolve instantaneously, releasing drugs within a few seconds without the need of water. The main objective of this paper was to prepare and develop ODTs of clopidogrel. The ODTs were prepared by direct compression. The effect of three superdisintegrants, namely crospovidone, croscarmellose sodium, and sodium starch glycolate, using three different disintegration times on the dissolution rate was investigated. The prepared tablets were evaluated for hardness, friability, disintegration time and in vitro drug release. Furthermore, the interaction of clopidogrel with the formulation excipients was studied using differential scanning calorimetry (DSC). DSC studies revealed that there were no interactions between the drug and the excipients used. All tablets had hardness values in the range 4.0-5.2 kp and friability lower than $1 \%$. The weight and drug content uniformity of all formulations was within official limits according to BP. In vitro drug release studies of the ODTs showed that more than $90 \%$ of the drug was released within ten minutes. A palatability test in human volunteers showed acceptable taste and mouth feel. Thus, the obtained results conclusively demonstrated successful rapid disintegration of the formulated tablets and acceptable palatability.

Uniterms: Clopidogrel/orally disintegrating tablets. Superdisintegrants. Orally disintegrating tablets/ formulation. Orally disintegrating tablets/evaluation.

Recentes avanços em sistemas de liberação de fármacos novos visam à obtenção de melhor adesão do paciente. Um destes avanços é a formulação de comprimidos de desintegração oral (ODTs), que se dissolvem instantaneamente, liberando o fármaco, em alguns segundos, sem a necessidade de água. O principal objetivo deste trabalho foi preparar e desenvolver ODTs de clopidogrel. Os ODTs foram preparados pelo método de compressão direta. Estudou-se o efeito de várias concentrações de diferentes agentes de desintegração, tais como super-crospovidona, croscarmelose de sódio, glicolato de amido de sódio no tempo de desintegração e velocidade de dissolução. Os comprimidos preparados foram avaliados quanto à dureza, à friabilidade, ao tempo de desintegração e à liberação do fármaco in vitro. Além disso, estudou-se a interação de clopidogrel com os excipientes de formulação, utilizando calorimetria de varredura diferencial (DSC). Estudos de DSC revelaram não haver interação entre o fármaco e os excipientes utilizados. Todos os comprimidos possuíam dureza na faixa de 4,0-5,2 kp e a friabilidade inferior a $1 \%$. A variação de peso e o teor de fármaco de todas as formulações mostraram-se dentro do limite oficial, de acordo com a BP. O estudo de liberação do fármaco in vitro de comprimidos ODTs mostrou que mais de $90 \%$ do fármaco foram liberados em 10 minutos. O teste de palatabilidade em voluntários humanos mostrou sabor e sensação na boca aceitáveis. Assim, os resultados obtidos demonstraram, conclusivamente, a rápida e bem-sucedida desintegração dos comprimidos formulados e a palatabilidade aceitável.

Unitermos: Clopidogrel/comprimidos de desintegração oral. Superdesintegrantes. Comprimidos/de desintegração oral/formulação. Comprimidos/de desintegração oral/avaliação.

"Correspondence: Gamal Mohamed Mahrous. Department of Pharmaceutics. College of Pharmacy. King Saud University. Riyadh 11454. P.O. Box 2457. Kingdom of Saudi Arabia. E-mail: gmmahroos@yahoo.com 


\section{INTRODUCTION}

Formulations administered via the oral route represent $50-60 \%$ of the total pharmaceutical dosage forms in the market (Bandelin, 1989). The oral administration route is considered to be the most widely accepted route because of its convenience, ease of administration, avoidance of pain and patient compliance (Bandelin, 1989). However, many paediatric and geriatric patients are unwilling to take solid preparations due to a fear of choking or because of difficulty in swallowing (dysphagia). Also, the swallowing of oral dosage forms requires water, which might be not available in some cases (Kuccherkar, Badhan, Mahajan, 2003; Suresh et al., 2008). For these reasons, tablets that can rapidly dissolve or disintegrate in the oral cavity have attracted a great deal of attention (Porter, 2001; Mostafa, Ibrahim, Sakr, 2013). These tablets are called fast dissolving tablets, orally disintegrating tablets (ODTs) or mouth-dissolving tablets. Fast dissolving tablets are those which, when put onto the tongue, disintegrate instantaneously releasing the drug, which dissolves or disperses in the saliva (Venkateswara, Nyshadham, Joseph, 2003). Orally disintegrating tablets are defined as solid oral preparations that disintegrate rapidly in the oral cavity with an in vitro disintegration time of less than 30 seconds, according to FDA guidelines (DHHS, 2008).

The use of superdisintegrants is essential in development of orally disintegrating tablets. Examples of these are: cross-linked carboxymethyl cellulose $\left(\right.$ croscarmellose $^{\circledR}$ ), sodium starch glycolate (primogel ${ }^{\circledR}$, explode $^{\circledR}$ ) and crospovidone (polyplasdone ${ }^{\circledR}$ ). These superdisintegrants provide instantaneous disintegration of the tablet when it is placed on the tongue. The bioavailability of some drugs may be increased due to absorption of some of the drug in the oral cavity, and also due to pregastric absorption of saliva containing dispersed drug that passes down into the stomach. Moreover, the amount of drug that is subjected to first pass metabolism is reduced compared with conventional tablets (Biradar, Bhagavati, Kuppasad, 2006).

Clopidogrel hydrogen sulphate (named hereafter clopidogrel) was discovered by Sanofi. It is now marketed by Sanofi-Synthelabo worldwide under the brand name PLAVIX ${ }^{\circledR}$. Clopidogrel is an antiplatelet agent, which selectively inhibits the binding of adenosine diphosphate (ADP) to its platelet receptor and blocks the subsequent GPIIb/IIIa complex, thereby inhibiting platelet aggregation (Jarvis, Simpson, 2000). The clinical benefits of clopidogrel have been demonstrated and it is used worldwide for the long-term prevention of atherothrombotic events such as myocardial infarction, stroke, peripheral arterial disease and acute coronary syndrome (Jarvis, Simpson, 2000).

In a previous study, Sahitya et al. (2014) formulated a solid dispersion of clopidogrel into fast dissolving tablets. However, such formulations have reduced palatability due to the rapid dissolution in the mouth.

The aim of the present work was to prepare fast disintegrating clopidogrel tablets by direct compression and to study the effect of the type and concentration of the superdisintegrant used on the physical properties of the prepared tablets, as well as on drug dissolution and disintegration. The direct compression technique was selected rather than wet granulation because the porous nature of tablets prepared by direct compression results in faster disintegration.

\section{MATERIAL AND METHODS}

Clopidogrel hydrogen sulphate (CL) was kindly donated by Tabuk Pharmaceutical manuf. Co, Tabuk, Saudi Arabia. Microcrystalline cellulose (Avicel ${ }^{\circledR}$ PH101) was purchased from Serva Feinbiochemica (Heidelberg, Germany). Spray dried mannitol (Mannogem ${ }^{\mathrm{TM}} \mathrm{EZ}$ ), used as a filler for the orally disintegrating tablets, was kindly supplied by SPI, Grand Haven, USA. Croscarmellose sodium (CCS), sodium starch glycolate (SSG) and crospovidone (CPV) were kindly supplied by Riyadh Pharma, Riyadh, KSA. Magnesium stearate was purchased from Riedel-de Haën, Seelze, Germany. Potassium dihydrogen orthophosphate and Sodium hydroxide were purchased from Merck, Darmstadt, Germany.

\section{METHODOLOGY}

\section{Differential scanning calorimetry (DSC)}

The thermal behaviour of CL alone and in physical mixtures with tablet excipients was studied using DSC. Samples (3-5 mg) were weighed and hermetically sealed in aluminium pans and heated at a constant rate of $10^{\circ} \mathrm{C} / \mathrm{min}$, in a temperature range from $25^{\circ} \mathrm{C}$ to $250^{\circ} \mathrm{C}$. Thermograms of the samples were obtained using differential scanning calorimetry (DSC-60, Shimadzu, Japan). Thermal analysis data were recorded using a TA 50I PC system with Shimadzu software programs. An indium standard was used to calibrate the DSC temperature and enthalpy scale. $\mathrm{N}_{2}$ was used as the purging gas at a rate of $30 \mathrm{~mL} / \mathrm{min}$.

\section{Fourier transform infrared spectroscopy (FTIR)}

The FTIR spectra of TNX, KL and their binary 
systems were recorded using a Perkin Elmer FTIR spectrophotometer (Spectrum BX). Samples were mixed with potassium bromide (spectroscopic grade) and compressed into disks using a hydraulic press before scanning from 4000 to $600 \mathrm{~cm}^{-1}$. The data were analysed using Perkin Elmer software (Spectrum V5.3.1).

\section{Pre-compression evaluation}

The flow properties of the powder mixtures of different compositions were evaluated in terms of their bulk density, tapped density, angle of repose, Carr's index and Hausner ratio.

\section{Preparation of clopidogrel hydrogen sulphate (CL) tablets by direct compression}

The calculated amounts of CL, superdisintegrant and microcrystalline cellulose (MCC 101) shown in Table 1 were accurately weighed and blended in a Turbula mixer (Erweka, S2Y, Heusenstamm, Germany) for five minutes. Thereafter, the formula weight of mannitol was mixed with the MCC-superdisintegrant mixture for $10 \mathrm{~min}$. Finally, the correct amount of magnesium stearate was mixed with the powder blend for a further 2 minutes. After mixing, the powder blend was compressed into shallow concave tablets weighing $300 \mathrm{mg}$ using a Korsh single punch machine with $9 \mathrm{~mm}$ punches (Erweka, EKO, Germany).

\section{Evaluation of the prepared tablets}

Weight variation

Twenty tablets from each batch were individually weighed (Analytical balance, Shimadzu, EB-3200D, Tyoto, Japan) and the average weight $\pm \mathrm{SD}$ was calculated.

\section{Hardness}

The tablet crushing strength (hardness) was investigated using a hardness tester (Pharma test $\mathrm{GmbH}$, Hainburg, Germany) for samples of 10 compressed tablets for each tablet formula. The average values of weight \pm SD were recorded.

\section{Friability}

The percentage loss in weight of tablets (friability) was calculated based on the pharmacopeial test (USP, 2011, 34-NF29). Twenty accurately weighed tablets $\left(\mathrm{W}_{1}\right)$ were placed in the friability tester (Erweka, TA3R, Heusenstamm, Germany), and allowed to rotate for $4 \mathrm{~min}$ at $25 \mathrm{rpm}$. After removal of fines, tablets were reweighed $\left(\mathrm{W}_{2}\right)$, and the percentage weight loss was calculated from the following equation:

$$
100 \times\left(\mathrm{W}_{1}-\mathrm{W}_{2}\right) / \mathrm{W}_{1} .
$$

\section{Clopidogrel content}

An orally disintegrating clopedogril tablet weighing $300 \mathrm{mg}$ and equivalent to $75 \mathrm{mg}$ clopedogril was accurately weighed, finely powdered, and transferred into a volumetric flask. About $60 \mathrm{~mL}$ of $0.1 \mathrm{~N} \mathrm{HCl}$ was added and the flask was sonicated for $10 \mathrm{~min}$, then shaken mechanically for $30 \mathrm{~min}$ and the volume made up to $100 \mathrm{~mL}$ with the same solvent, followed by sonication and filtration. The drug content was determined spectrophotometrically at $240 \mathrm{~nm}$ (Ashraf Z. et al.; 2015). The test was repeated for ten individual tablets and the

TABLE I - Composition of various clopidogrel hydrogen sulphate (CL) orally disintegrating tablet formulations

\begin{tabular}{lccccccc}
\hline Formula & \multicolumn{7}{c}{ Ingredients (\%w/w) } \\
\cline { 2 - 8 } & CL & MCC & Mannitol & CCS & SSG & CPV & $\begin{array}{r}\text { Aspartame \& } \\
\text { mag-stearate }\end{array}$ \\
\hline F1 & 25 & 36 & 36 & - & - & - & 2,1 \\
F2 & 25 & 35.0 & 35.0 & 2.0 & - & - & 2,1 \\
F3 & 25 & 33.5 & 33.5 & 5.0 & - & - & 2,1 \\
F4 & 25 & 31.0 & 31.0 & 10.0 & - & - & 2,1 \\
F5 & 25 & 35.0 & 35.0 & - & 2.0 & - & 2,1 \\
F6 & 25 & 33.5 & 33.5 & - & 5.0 & - & 2,1 \\
F7 & 25 & 31.0 & 31.0 & - & 10.0 & - & 2,1 \\
F8 & 25 & 35.0 & 35.0 & - & - & 2.0 & 2,1 \\
F9 & 25 & 33.5 & 33.5 & - & - & 5.0 & 2,1 \\
F10 & 25 & 31.0 & 31.0 & - & - & 10.0 & 2,1 \\
\hline Th & 25 &
\end{tabular}

The total tablet weight was $300 \mathrm{mg}$. CL: Clopidogrel, MCC: Microcrystalline cellulose (Avicel PH 101), CCS: Crosscarmelose sodium, SSG: Sodium starch glycolate, CPV: Crospovidone 
average drug content $\pm \mathrm{SD}$ was presented.

\section{In vitro disintegration}

The disintegration times of the manufactured tablets were evaluated in vitro using a USP disintegration apparatus operated at $37^{\circ} \mathrm{C} \pm 2{ }^{\circ} \mathrm{C}$, using phosphate buffer (pH 6.8) as the disintegration medium (USP 34-NF29; 2011). One tablet was introduced into each of the six tubes of the basket (Electrolab, ED-21, Pumbai, India). The time required for complete tablet disintegration was recorded and the mean $\pm \mathrm{SD}$ of six tablets was calculated.

\section{In vitro dissolution studies}

The release measurements were performed using a USP dissolution apparatus 2 (Caleva Ltd., Model 85T), using the paddle method at $50 \mathrm{rpm}$. Each flask contained $500 \mathrm{~mL} 0.1 \mathrm{~N} \mathrm{HCl}$, adjusted to $\mathrm{pH} 2.0$ or phosphate buffer at $\mathrm{pH} 6.8$ maintained at $37 \pm 0.5^{\circ} \mathrm{C}$. At predetermined time points $(5,10,15,20$ and 30 minutes), a $5 \mathrm{~mL}$ sample was withdrawn and replaced with fresh dissolution medium. The absorbances of the withdrawn samples were measured spectrophotometrically at $240 \mathrm{~nm}$ and the percentage of drug dissolved was calculated. The test was performed on CL containing tablets in triplicate.

\section{In vivo disintegration and palatability studies}

Ten healthy male volunteers (18-55 years old) were administered the selected formula (F9). The tested formula was allowed to disintegrate in the mouth and then disgorged. The taste, its extent, the after taste and other effects such as numbness (if any) were recorded as displayed in Table II. The study was approved by the King Saud University Ethics committee, Riyadh, Saudi Arabia.

\section{RESULTS AND DISCUSSION}

\section{Differential scanning calorimetry (DSC) and Fourier transform infrared spectroscopy (FTIR)}

Differential scanning calorimetry (DSC) was used to evaluate the melting point, crystallinity, decomposition and drug-excipient interaction by studying the thermal behaviour of the preparations (El Badry, 2008). DSC scans were performed on the drug, the tested excipients and their corresponding physical mixtures. The DSC scan of untreated clopidogrel showed a characteristic endothermic peak at $184{ }^{\circ} \mathrm{C}$ (Figure 1), which corresponds to its melting point. None of the tested additives had characteristic peaks in the temperature range studied, except for mannitol, which showed a sharp peak at $168{ }^{\circ} \mathrm{C}$ (Figure 2). For the corresponding physical mixtures of the drug with all of the additives except mannitol, the characteristic endothermic peak of the drug was seen in its melting range (184 \pm 3 ${ }^{\circ} \mathrm{C}$ ), but with lower intensity (Figure 2). This indicates that there is no interaction between clopidogrel and these excipients. Upon scanning the DSC thermogram of the drug-mannitol physical mixture, the drug fusion peak appeared at about $154{ }^{\circ} \mathrm{C}$ suggesting an interaction between the drug and mannitol.

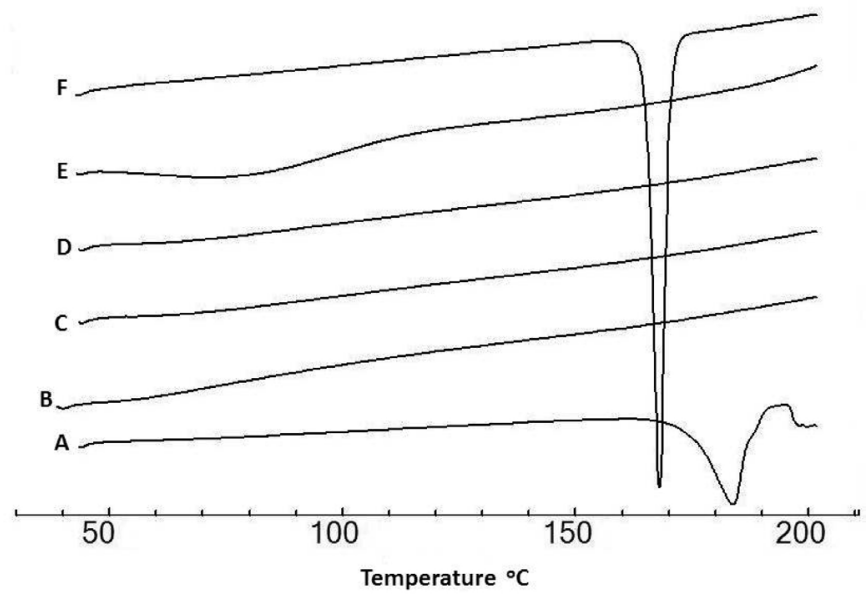

FIGURE 1 - Differential scanning calorimetric (DSC) thermograms of the drug and the tested excipients: (A) Clopidogrel; (B) Microcrystalline cellulose; (C) Crospovidone; (D) Starch sodium glycolate; (E) Croscarmellose; (F) Mannitol.

IR spectra (Figure 3) of clopidogrel, mannitol and their physical mixture were recorded in order to determine whether there was a chemical interaction between them. The IR spectrum of clopidogrel is characterised by principal absorption peaks at $3107.16 \mathrm{~cm}^{-1}(\mathrm{C}-\mathrm{H}$ aromatic), $1752 \mathrm{~cm}^{-1}(\mathrm{C}=\mathrm{O}$ stretching $)$, and $1178 \mathrm{~cm}^{-1}$ (C-O stretching) (Shailendra, Soukarya, Upender, 2011).

TABLE II - Palatability evaluation

\begin{tabular}{|c|c|c|c|c|c|}
\hline \multirow{2}{*}{ Effect } & \multicolumn{4}{|c|}{ Scale } & \multirow{2}{*}{$\begin{array}{c}\text { After Effects } \\
+\end{array}$} \\
\hline & 1 & 2 & 3 & 4 & \\
\hline Taste & $\mathrm{Bad}$ & Acceptable & Good & Excellent & After taste \\
\hline Mouth feel & Gritty & Acceptable & Good & Excellent & Numbness \\
\hline
\end{tabular}




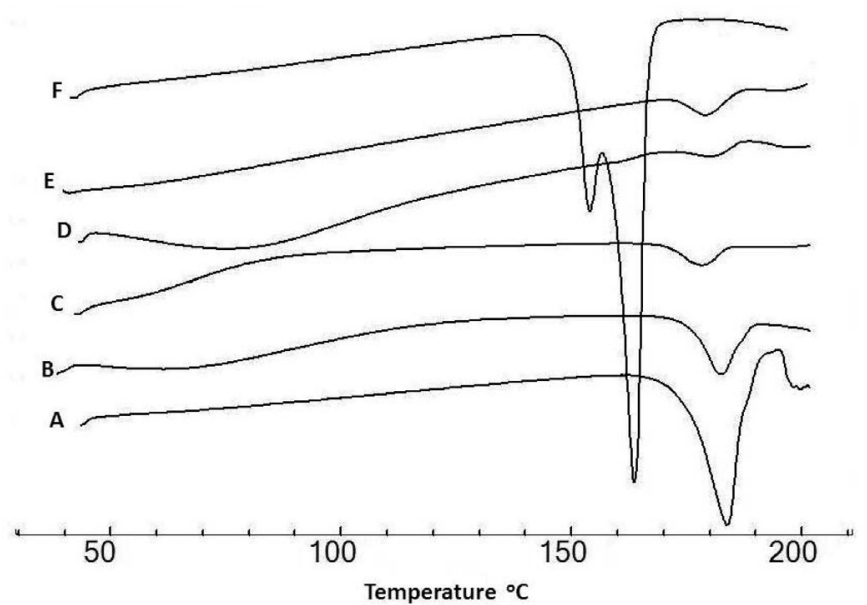

FIGURE 2 - Differential scanning calorimetric (DSC) thermograms of clopidogrel and its physical mixtures with the tested excipients: (A) Clopidogrel; (B) drug:microcrystalline cellulose; (C) drug:crospovidone; (D) drug:starch sodium glycolate; (E) drug:croscarmellose; (F) drug:mannitol.

All of the principal absorption beaks of clopidogrel appeared in the physical mixture at the same positions. No additional peaks were observed in case of the physical mixture. These results indicate that there is no chemical interaction between clopidogrel and mannitol.

\section{Pre-compression evaluation}

The blends of the drug and various tablet excipients were evaluated for their micromeritic characteristics as shown in Table III. The calculated bulk density was between $0.39-0.44 \mathrm{~g} / \mathrm{cc}$ and the tapped density was between $0.398 \pm 0.007$ and $0.43-0.50 \mathrm{gm} / \mathrm{cc}$ for all tested

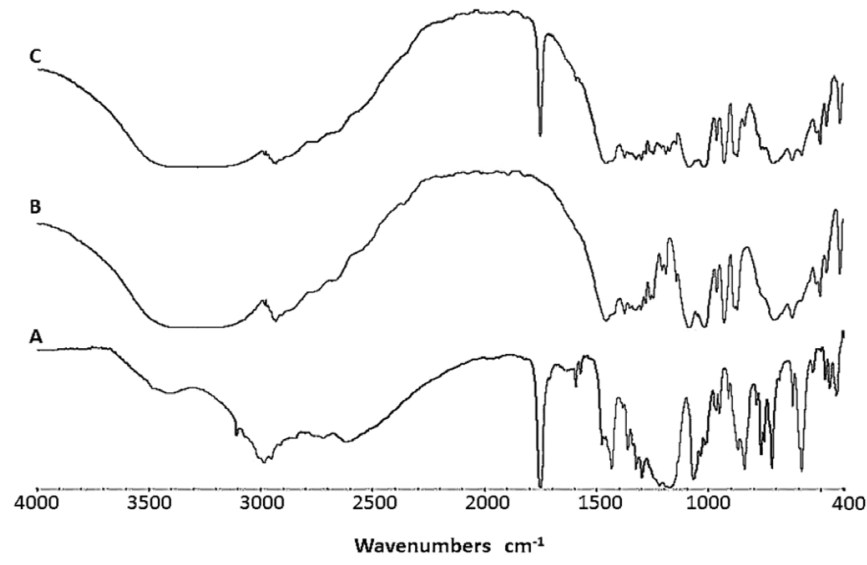

FIGURE 3 - FTIR spectra of: A) clopidogrel, B) mannitol, C) clopidogrel:mannitol physical mixture.

powder blends. The angle of repose and Carrs indices were found to be in the ranges $31.0-34.5$ and $10-12.5 \%$, respectively. The Hausner ratio was found to be below 1.15. All of the formulations showed the good blend properties required for direct compression and hence tablets were prepared using direct compression.

\section{Tablet Evaluation}

The manufactured ODTs containing $75 \mathrm{mg} \mathrm{CL}$ were successfully prepared using the direct compression method. The manufactured ODTs were evaluated for their weight uniformity, hardness, friability, and CL content as well as for their disintegration time, and the obtained data are summarised in Table 4 . The measured tablet weights ranged from $0.295-0.304 \mathrm{~g}$ and the average tablet hardness was found to be $4.2-5.2 \mathrm{kp}$. Moreover, the tablets exhibited

TABLE III - The precompression parameters of the powder blends

\begin{tabular}{lccccc}
\hline Formulation code & $\begin{array}{c}\text { Angle of } \\
\text { repose(囚) }\end{array}$ & $\begin{array}{c}\text { Bulk density } \\
(\mathbf{g} / \mathbf{c c})\end{array}$ & $\begin{array}{c}\text { Tapped density } \\
\text { (g/cc) }\end{array}$ & $\begin{array}{c}\text { Carr's index } \\
(\mathbf{\%})\end{array}$ & Hausner Ratio \\
\hline F1 & $32.4 \pm 0.48$ & $0.44 \pm 0.005$ & $0.50 \pm 0.006$ & 12.28 & 1.14 \\
F2 & $33.3 \pm 0.58$ & $0.42 \pm 0.004$ & $0.46 \pm 0.004$ & 10 & 1.1 \\
F3 & $34 \pm 0.68$ & $0.41 \pm 0.005$ & $0.46 \pm 0.005$ & 11.48 & 1.13 \\
F4 & $34.5 \pm 0.66$ & $0.4 \pm 0.004$ & $0.45 \pm 0.004$ & 11.29 & 1.13 \\
F5 & $33 \pm 0.61$ & $0.4 \pm 0.003$ & $0.45 \pm 0.004$ & 11.29 & 1.13 \\
F6 & $33.5 \pm 0.60$ & $0.39 \pm 0.003$ & $0.43 \pm 0.005$ & 9.57 & 1.04 \\
F7 & $33.6 \pm 0.58$ & $0.39 \pm 0.004$ & $0.45 \pm 0.006$ & 12.5 & 1.14 \\
F8 & $30.4 \pm 0.35$ & $0.42 \pm 0.003$ & $0.46 \pm 0.003$ & 10 & 1.13 \\
F9 & $31 \pm 0.40$ & $0.41 \pm 0.004$ & $0.46 \pm 0.004$ & 11.48 & 1.13 \\
F10 & $31.8 \pm 0.49$ & $0.39 \pm 0.004$ & $0.43 \pm 0.004$ & 9.4 & 1.1 \\
\hline
\end{tabular}

Mean of three experiments (mean $\pm \mathrm{SD})$. 
TABLE IV - Physical properties of orally disintegrating clopidogrel tablets (Mean \pm SD)

\begin{tabular}{lccccc}
\hline & $\begin{array}{c}\text { Weight } \\
(\mathbf{m g})\end{array}$ & $\begin{array}{c}\text { Disintegration } \\
\text { time* (sec.) }\end{array}$ & $\begin{array}{c}\text { CL Content } \\
\text { (\%)+/-SD }\end{array}$ & $\begin{array}{c}\text { Hardness } \\
\text { (Kp) }\end{array}$ & $\begin{array}{c}\text { Friability } \\
\text { (\%) }\end{array}$ \\
\hline F1 & $299 \pm 0.39$ & $236 \pm 5.0$ & $101.30 \pm 0.51$ & $4.0 \pm 0.50$ & $0.86 \pm 0.10$ \\
F2 & $301 \pm 0.54$ & $29 \pm 0.87$ & $99.50 \pm 0.42$ & $4.8 \pm 0.28$ & $0.81 \pm 0.15$ \\
F3 & $300 \pm 0.72$ & $24 \pm 0.58$ & $98.80 \pm 0.50$ & $4.8 \pm 0.16$ & $0.87 \pm 0.14$ \\
F4 & $304 \pm 0.63$ & $24 \pm 0.60$ & $100.10 \pm 0.66$ & $4.8 \pm 0.19$ & $0.74 \pm 0.24$ \\
F5 & $298 \pm 0.61$ & $58 \pm 1.0$ & $101.00 \pm 0.72$ & $5.1 \pm 0.21$ & $0.79 \pm 0.16$ \\
F6 & $302 \pm 0.37$ & $53 \pm 1.00$ & $98.77 \pm 0.53$ & $5.1 \pm 0.23$ & $0.70 \pm 0.31$ \\
F7 & $299 \pm 0.49$ & $53 \pm 1.00$ & $101.30 \pm 0.60$ & $4.6 \pm 0.34$ & $0.75 \pm 0.21$ \\
F8 & $301 \pm 0.73$ & $22 \pm 1.53$ & $102.10 \pm 0.80$ & $4.6 \pm 0.28$ & $0.76 \pm 0.20$ \\
F9 & $299 \pm 0.68$ & $17 \pm 0.58$ & $103.20 \pm 0.63$ & $5.2 \pm 0.49$ & $0.79 \pm 0.21$ \\
F10 & $302 \pm 0.38$ & $17 \pm 1.00$ & $101.30 \pm 0.66$ & $4.2 \pm 0.30$ & $0.88 \pm 0.11$ \\
\hline
\end{tabular}

* Experiments were carried out in phosphate buffer (pH 6.8).

acceptable friability that was less than $1 \%$ in all ODT formulations.

\section{Tablet Disintegration}

The impact of the use of different disintegrants on the time required for disintegration of the ODTs containing $75 \mathrm{mg}$ CL is displayed in Table IV.

It is clearly evident from the data that the superdisintegrants used caused a pronounced decrease in the disintegration time of the prepared ODTs, especially CCS and CPV. Tablets formulated without superdisintegrants exhibited a disintegration time of about 236 seconds.

Using CCS and CPV as superdisintegrants, when the concentration of the superdisintegrant was increased from $2 \%$ to $5 \%$, enhanced tablet disintegration was observed. Increasing the concentration of CCS or CPV from $5 \%$ to $10 \%$ in the tablets did not show any further significant increase in the disintegration rate. Also, increasing the concentration of SSG from $2 \%$ to $5 \%$ resulted in a reduction of the disintegration time from 58 seconds to 53 seconds, while increasing the concentration of the superdisintegrant from $5 \%$ to $10 \%$ did not show any further significant change. It can be concluded that the optimum concentration of superdisintegrant is $5 \%$, which gave rapid disintegration of CL tablets. These results are in agreement with those found by Ferrero et al., who studied the disintegration efficiency of croscarmellose sodium and reported that at high concentrations $(>8 \%)$, the disintegration time was found to be longer (Ferrero et al., 1997). Moreover, Jagdale et al. (2010) mentioned that CCS gave a short disintegration time at low concentrations with a sudden rise when the concentration was increased from $4 \%$ to $6 \%$. The authors interpreted these results on the basis of that the fibrous nature of CCS at low concentrations is responsible for its disintegrating action, which results from the wicking of water into tablet matrices. The fibrous nature of CCS is more pronounced at lower concentrations and smoothens gradually with time. There is a probability that wicking and swelling occur simultaneously, thus, at high concentrations smoothening of the particles and decrease in the width of the pores may prevail (Jagdale et al., 2010).

The tablet formulation containing 5\% CPV (F9) could be considered as optimum as it had shortest disintegration time. These results are in accordance with an earlier study by Balasubramaniam et al. (2008), where the disintegration time of clopidogrel tablets containing Polyplasdone XL showed the fastest release in compendial medium ( $\mathrm{pH}$ 2.0), compared with SSG and croscarmellose sodium. The authors explained their results on the basis that of the commonly used superdisintegrants, crospovidone is nonionic, while SSG and croscarmellose sodium are anionic. It has been proposed that any weakly basic (cationic) drug, when present in an environment where the $\mathrm{pH}$ is $>2$ and near or below the $\mathrm{pKa}$ of the cationic drug, should be expected to interact with ionised polymers like croscarmellose sodium and SSG (Balasubramaniam et al., 2008).

\section{In vitro dissolution}

The in vitro dissolution profiles of CL from the prepared orally disintegrating tablets in the compendial medium ( $\mathrm{pH}$ 2.0) are displayed in Figures 4-6. The drug exhibited only $5 \%$ dissolution from the tablet formula without superdisintegrant after the first 5 minutes, and 
completed dissolution after 20 minutes. This observation was in agreement with the higher disintegration times expected with such formulas. However, the presence of superdisintegrants in the tablet formulations caused an enhanced initial dissolution rate of CL, especially at the $5 \%$ superdisintegrant level. For example, more than $95 \%$ of the loaded CL dissolved from ODTs containing a $5 \%$ concentration of CCS, CPV or SSG after 5 minutes.

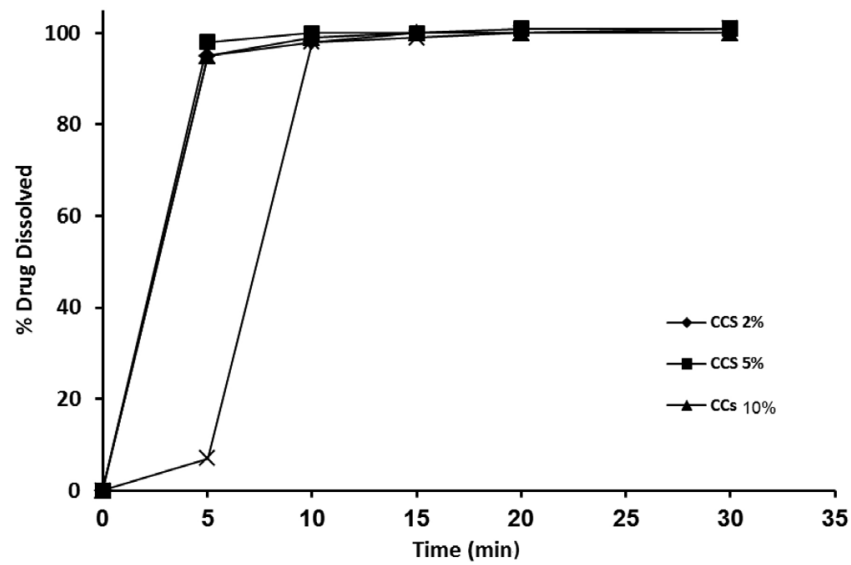

FIGURE 4 - Effect of CCS concentration on the percentage of Clopidogrel dissolved in an acidic medium, $\mathrm{pH}$ 2.0.

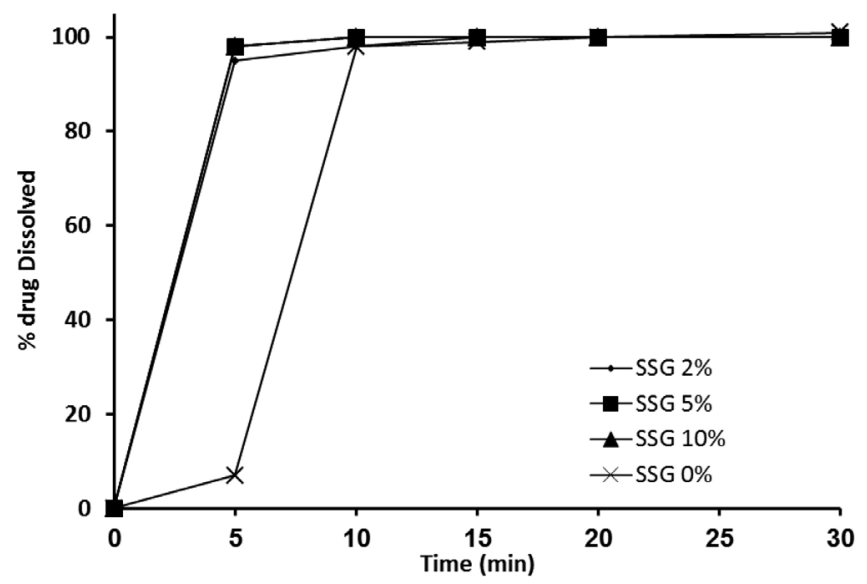

FIGURE 5 - Effect of SSG concentration on the percentage of Clopidogrel dissolved in an acidic medium, $\mathrm{pH}$ 2.0.

The dissolution CL from ODT formulations F3, F6 and F9 (containing 5\% each of CCS, SSG, and CPV, respectively) was studied in two different dissolution media, at $\mathrm{pH} 2.0$ and $\mathrm{pH} 6.8$ and the results are displayed in Figure 7.

Clopidogrel exhibited very slow dissolution rates from the formulas at the higher $\mathrm{pH}$ value (no more than $30 \%$ was released after 30 minutes), while complete drug dissolution from both formulas was observed after 15 minutes at the lower $\mathrm{pH}(\mathrm{pH} 2.0)$. This phenomenon is due

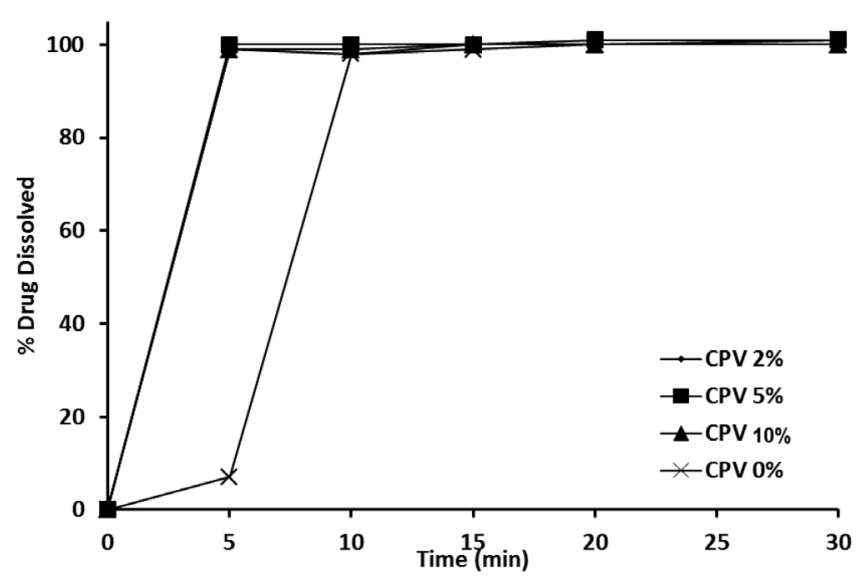

FIGURE 6 - Effect of CPV concentration on the percentage of Clopidogrel dissolved in an acidic medium, $\mathrm{pH} 2.0$.

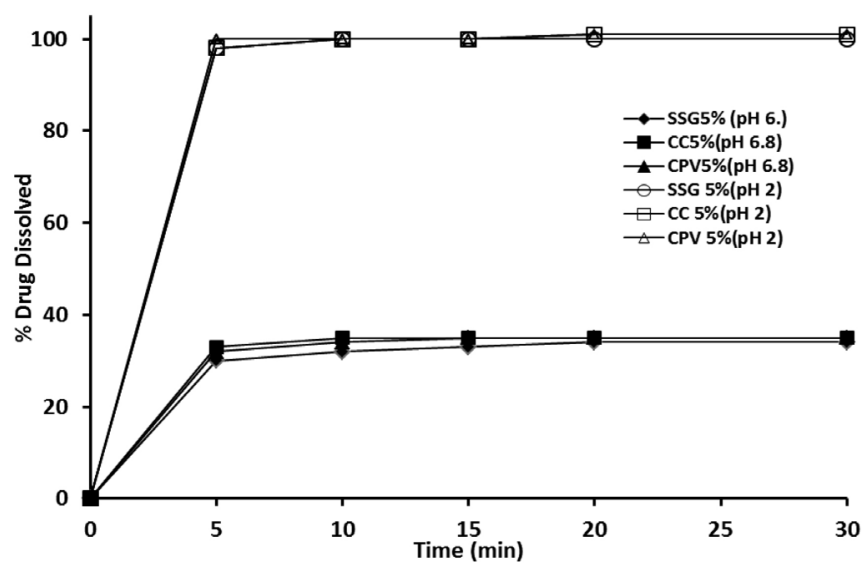

FIGURE 7 - Effect of the $\mathrm{pH}$ of the dissolution medium on the percentage of Clopidogrel dissolved.

to the lower solubility of $\mathrm{CL}$ at higher $\mathrm{pH}$ values because of its basic nature (Sahitya et al., 2014). This might be advantageous during the formulation of CL ODTs, since the manufactured ODTs formulations containing the drug exhibited rapid disintegration at the higher $\mathrm{pH}$ value $(\mathrm{pH}$ 6.8), which simulates saliva fluid, while the drug dissolves slowly, which may mask its undesirable taste.

\section{Evaluation of palatability}

The results of palatability test were illustrated in Tables V and VI. Half of the volunteers reported that the palatability was acceptable while the other half reported good palatability. Only two volunteers out of ten complained of a mild bitter after taste. In evaluation of mouth feel, eight of the volunteers reported that it was acceptable while the other two exhibited taste responses with no complaints of numbness. These results indicate the acceptable palatability of the formulated tablets. The mean in vivo disintegration time for the ten volunteers was 
TABLE V - Taste evaluation results for the selected formula (F9)

\begin{tabular}{llllccc}
\hline Volunteer No. & \multicolumn{2}{c}{ Scale } & Aftertaste & $\begin{array}{c}\text { In vivo disintegration } \\
\text { time (Sec.) }\end{array}$ \\
\cline { 2 - 6 } & $\mathbf{1}$ & $\mathbf{2}$ & $\mathbf{3}$ & $\mathbf{4}$ & - & 11 \\
2 & & $\mathrm{X}$ & & - & 9 \\
3 & & $\mathrm{X}$ & $\mathrm{X}$ & - & 12 \\
4 & & $\mathrm{X}$ & + & 9 \\
5 & & $\mathrm{X}$ & - & 10 \\
6 & $\mathrm{X}$ & & - & 10 \\
7 & $\mathrm{X}$ & & - & 14 \\
8 & $\mathrm{X}$ & & - & 12 \\
9 & $\mathrm{X}$ & & + & 8 \\
10 & $\mathrm{X}$ & & - & 8 \\
\hline
\end{tabular}

TABLE VI - Mouth feel evaluation results for the selected formula (F9)

\begin{tabular}{|c|c|c|c|c|c|}
\hline \multirow{2}{*}{ Volunteer No. } & \multicolumn{4}{|c|}{ Scale } & \multirow{2}{*}{ Numbness } \\
\hline & 1 & 2 & 3 & 4 & \\
\hline 1 & & $\mathrm{X}$ & & & - \\
\hline 2 & & & $\mathrm{X}$ & & - \\
\hline 3 & & & $\mathrm{X}$ & & - \\
\hline 4 & & $\mathrm{X}$ & & & - \\
\hline 5 & & $\mathrm{X}$ & & & - \\
\hline 6 & & & & & - \\
\hline 7 & & $\mathrm{X}$ & & & - \\
\hline 8 & & $\mathrm{X}$ & & & - \\
\hline 9 & & $\mathrm{X}$ & & & - \\
\hline 10 & & $\mathrm{X}$ & & & - \\
\hline
\end{tabular}

about ten seconds, which is in accordance with the in vitro disintegration time for F9.

\section{CONCLUSION}

In conclusion, ODTs of CL were developed that had sufficient mechanical integrity, and uniformity of content with acceptable palatability to allow easy administration to patients of any age group. The ODTs were prepared by direct compression. All tablets had hardness in the range $4.2-5.2 \mathrm{kp}$ and friability less than $1 \%$. Weight variation and drug content of all formulations were within official limits. In vitro disintegration tests and in vitro drug release studies of ODTs tablets showed a fast disintegration within seconds at pH 6.8 and more than $90 \%$ of the drug was released within 5 minutes in acidic medium.

\section{ACKNOWLEDGMENTS}

The authors would like to extend their sincere appreciation to the Deanship of Scientific Research at King Saud University for its funding this Research group No. RGP -299.

\section{REFERENCES}

ASHRAF, Z.; KHURRAM, S.; MAQBOOL, U.; KHAN, K.R.; AJAZ, U.; FATIMA, S.F.; NAZ, S.; MUNEER, F.; IRFAN, U.; AYUB, M. Assay of clopidogrel hydrogen sulphate in tablet form from different manufacturing sources by using UV spectroscopy. W. J. Pharm. Res., v.4, n.10, p.377-381, 2015 
BALASUBRAMANIAM, J.; BINDU, K.; RAO, V.U.; RAY, D.; HALDAR, R.; BRZECZKO, A.W. Effect of superdisintegrants on dissolution of cationic drugs. Dissol. Tech., May, p.18-25, 2008.

BANDELIN, F.J. Compressed tablets by wet granulation. In: LIEBERMAN, H.A.; LACHMAN, L.; SCHWARTZ, J.B. (ed.). Pharmaceutical dosage forms: tablets. New York: Marcel Dekker, 1989. v.1, p.131-94,

BIRADAR, S.S.; BHAGAVATI, S.T.; KUPPASAD, I.J. Fast dissolving drug delivery systems: a brief overview. Int. J. Pharmacol., v.4, n.2, 2006.

DEPARTMENT OF HEALTH AND HUMAN SERVICES. (DHHS). FOOD AND DRUG ADMINISTRATION. (FDA). CENTER FOR DRUG EVALUATION AND RESEARCH (CDER). Guidance for Industry. Orally Disintegrating Tablets; Rockville: CDER, 2008. Dec., p.1-6

EL-BADRY, M. Physicochemical characterization and dissolution properties of meloxicam-gelucire 50/13 binary systems. Sci. Pharm., v.79, n.2, p.375-86, 2011.

FERRERO, C.; MUÑOZ, N.; VELASCO, M.V.; MUÑOZRUIZ, A.; JIMÉNEZ-CASTELLANOS, R. Disintegrating efficiency of croscarmellose sodium in a direct compression formulation. Int. J. Pharm., v.147, n.1, p.11-21, 1997.

JAGDALE, S.C.; FERNANDES, N.C.; KUSHEKAR, B.S.; SHAH, T.P.; CHABUKSWAR, A.R. Selection of superdisintegrant for famotidine rapidly disintegrating tablets. J. Chem. Pharm. Res., v.2, n.2, p.65-72, 2010.

JARVIS, B.; SIMPSON, K. Clopidogrel: a review of its use in the prevention of atherothrom-bosis. Drugs, v.60, n.2, p.347-377, 2000.
KUCCHERKAR, B.S.; BADHAN, A.C.; MAHAJAN, H.S. Mouth dissolving tablets: A novel drug delivery system. Pharma. Times, v.35, p.3-10, 2003.

MOSTAFA, H.F.; IBRAHIM, M.A.; SAKR, A. Development and optimization of dextromethorphan hydrobromide oral disintegrating tablets: effect of formulation and process variables. Pharm. Develop. Tech., v.18, n.2, p.454-463, 2013.

PORTER, S. C. Novel drug delivery: review of recent trends with oral solid dosage forms. Am. Pharm. Rev., v.85, p.2835,2001 .

S A H I T Y A, A .; K R I S H N A M O O R T H Y, B . ; MUTHUKUMARAN, M.; KISHORE,G. Formulation and evaluation of fast dissolving tablets using solid dispersion of clopidogrel bisulphate. Int. J. Adv. Pharm. Gen. Res., v.2, n.1, p.15-23, 2014.

SHAILENDRA, K.S.; SOUKARYA, S.; UPENDER, S. Formulation and optimization of solid dispersion of Clopidogrel with PEG 6000. J. App. Pharm. Sci., v.1, n.8, p.217-226, 2011.

SURESH, B.; KUMAR, M.; RAMESH, G.; MADHUSUDAN, R. Orodispersible tablets: an overview. Asian J. Pharm., v.2, p.2-11, 2008.

VENKATESWARA S.S.; NYSHADHAM, J.R.; JOSEPH, A.F. Recent technological advances in oral drug delivery: a review. Pharm. Sci. Technol. To., v.3, p.138-145, 2003.

THE UNITED STATES PHARMACOPEIA (USP). National Formulary USP 34-NF 29. The United States Pharmacopeial Convention. Rockville: MD, 2011.

Received for publication on $28^{\text {th }}$ July 2015 Accepted for publication on $02^{\text {nd }}$ May 2016 
